JPPUMA: Journal of Governance and Socio-Political Sciences UMA (Journal of Governance and Political

Social UMA), 9 (2) (2021): 197-207, DOI: 10.31289/ippuma.v9i2.5081

JPPUMA: Journal of Governance and Socio-Political Sciences UMA (Journal of Governance and Political Social UMA)

Available online http://ojs.uma.ac.id/index.php/jppuma

\title{
Utilization of Online Media in the 2020 Simultaneous Regional Head Election Campaign in Semarang
}

\author{
Beti Wulansari* \& Haris Isa Pamungkas \\ Master of Political Science, Faculty of Social and Political Sciences, \\ Universitas Diponegoro, Indonesia
}

Submitted: 08 April 2021 ; Reviewed: 19 July 2021 ; Accepted: 19 August 2021

\begin{abstract}
This article highlights how the use of online media as a campaign tool amid the Corona Virus Disease 19 pandemic in the Simultaneous Election of Mayor and Deputy Mayor of Semarang in 2020. focused The problem on how the challenges faced by General Election organizers and Candidate Pairs in organizing campaigns through online media. To approach this problem, used Rogers and Storey's campaign theory references. The campaign is one of the crucial stages of the election. Still, during the pandemic, the mass mobilization typical of the movement is limited and prioritized online media. Data were collected through observation, survey questionnaires, and document literacy and analyzed qualitatively. This study concludes that the team successfully played a campaign strategy through the internet during this pandemic, especially online and social media. Online media in this campaign also assisted General Election Supervisory Agency Election organizers as a supervisory function in the Implementation of the campaign. However, in campaigning efforts through online media, it is necessary to encourage various parties to create good political education in the community.
\end{abstract}

Keywords: Campaign; Online Media; Political Education

How to Cite: Wulansari, B., \& Pamungkas, H.I., (2021). Utilization of Online Media in the 2020 Simultaneous Election Campaign in Semarang. JPPUMA: Journal of Governance and Political Social UMA (UMA Journal of Governance and Political Social), 9(2): 197-207

\begin{tabular}{lr}
\hline *Corresponding author: & ISSN 2549-1660 (Print) \\
E-mail: betiwulans@gmail.com & ISSN 2550-1305 (Online)
\end{tabular}




\section{INTRODUCTION}

2020 Regional Head Elections for Governors and Deputy Governors, Regents and Deputy Regents and Mayors and Deputy Mayors, from now on referred to as the 2020 Simultaneous Elections, were held during the Corona Virus Disease 2019 (COVID-19) outbreak so that it became a challenge not only for eligible participants but also for the General Election Commission as the organizer of the 2020 Simultaneous Elections, as well as voters. On December 9, 2020, the Simultaneous Election was held well and smoothly while still prioritizing health protocols. It was not trivial to have an election amid a pandemic such as this since there were contradictory principles in its Implementation, but we must do it together.

One of the stages of an election that involves many people and can cause crowds is the campaign. The campaign is one of the key stages in the election; it is the right time for the candidate pair to present their image, convey their vision, mission, and work programs expected to influence voters to cast their votes. The stages of the election campaign should be identical to mass mobilization, such as general meetings, convoys, and grand movements. Still, during this pandemic, we must limit all gatherings that move large numbers of people. For this reason, smart voters are needed who can respond to these transitional changes to continue to create a healthy democratic climate while still complying with health protocols.

In this regard, the General Elections Commission issued General Election Commission Regulation (PKPU) Number 6 of 2020 concerning the Implementation of the Election of Governors and Deputy Governors, Regents and Deputy Regents, and Mayors and Deputy Mayors Simultaneously Continued in Non-Natural Disaster Conditions Corona Virus Disease 2019 (COVID-19). The regulation regulates the Implementation of the 2020 Simultaneous Election campaign amid this pandemic, where this regulation governs the Implementation of the Concurrent Simultaneous Regional Head and Deputy Regional Head elections in the Non-Natural Disaster Conditions Corona Virus Disease 2019 (COVID-19), which has been last amended by the Election Commission Regulation. General Number 13 of 2020. However, in each new thing, some adjustments must be made by many parties in its Implementation.

Bustami in Umayasari (2020) stated the challenges in holding the regional head election include adherence to the Implementation of health protocols at the election implementation stage, coordination and communication of election organizers is hampered due to the quality of the internet network, standardization process, and procurement of Personal Protective Equipment (PPE) who is prone to violations, and election participants will tend to violate health protocols during the campaign.

In the era of digital transformation, 4.0 was based on Danuri (2019). Digital transformation is a change in how a job is handled by using information technology to gain efficiency and effectiveness. Online media can be interpreted as a communication channel online via the internet, containing photos, videos, and text. Along with the growth of existing technology, online media can provide information and education to the public. Social media is also one form of online media widely used as a digital campaign platform for the 2020 simultaneous elections (KSIP, 2020).

In Indonesia itself, several conditions cause the increasing level of internet use as one of the strategies in political communication in Indonesia, one of them based on Indrawan (2020) is that the internet is a new medium since the internet is a combination that can be seen in terms of visual, motion and sound. For instance, video calls or now in the form of online meetings that can provide two-way 
communication, without having to meet face-to-face, we can talk to each other and greet people by looking directly at each other. Through the internet, candidates for regional heads can create Youtube channels or social media accounts to practice democracy in the political world. The candidates can use digital media as a means of socialization and their campaign.

$$
\text { In Central Java, the } 2020
$$

Simultaneous Elections were attended by 21 regencies/cities; one of them was Semarang. In Semarang, the use of online media is also used as a means of campaigning by candidates for Mayor and Deputy Mayor candidates to interact and introduce their profile and vision and mission in the 2020 Simultaneous Election. The event in Semarang is quite interesting because apart from Semarang being the capital of Central Java Province and being the axis of democracy in Central Java, the Candidate Pair for Mayor and Deputy Mayor is a single candidate pair against empty boxes. However, it does not reduce the importance of democracy since the candidate pair also continues to carry out the entire series of election stages, especially campaigns.

Semarang Health Office data shows that Semarang is still a Red zone category in Central Java Province; in November 2020, positive cases in Semarang still reached 13,096 points with 1,192 deaths. Therefore to anticipate the existence of a new cluster in the General Election in the 2020 Simultaneous Election Campaign stage, it is prioritized through online media.

In its development, online media, especially social media, has become an important tool in campaigning since it is considered effective for building political communication between regional heads and voters. Gina and Anna (2018) explained that the wider community often uses social media since it is considered easy to access anytime and anywhere. Therefore, social media and online media are very important since it is expected to be part of political education and voter education in the community. Based on Alfian (1981), political education is a conscious effort to change the political socialization process of society so that they truly appreciate and understand the values contained in the system.

However, the efforts that have been made by politicians using social media to get the attention of novice voters will not work perfectly if the younger generation is already apathetic and does not care about the world of politics (Munzir, 2019). Good use of social media does not necessarily affect good political knowledge either. The research of Dimitrova et al. (2014) suggested the effect of social media on political participation, but social media also has a weak impact on political knowledge.

In a previous study by Perdana, Aditya, and Delia (2018), they conducted a survey of campaign narratives and social media in the 2019 Presidential and VicePresidential Election. Based on the study, generally, they wanted a dynamic campaign in which the camps competed with each other, and the public could understand and know the programs they were running, the flagship program. The programmatic, which hasn't appeared yet, has implications for the emergence of issues amid society, especially related to ethnicity, religion, race, inter-group, and the stronghold of mass groups. Through a literature review, the study concludes that the use of campaigns in political education and political communication by election organizers and election participants requires strong commitment and synergy.

Ratnamulyani, Ike, and Beddy (2018) also examined the role of social media in increasing beginner voter participation among students in the Bogor Regency. Based on the questionnaire, the use of social media to access election information was increasingly massive among students. While among politicians, the use of social media for campaigning is still low at $82.7 \%$, and the campaign content of politicians is 
also less attractive, with results of $94.2 \%$. Therefore the input for politicians is to make more use of social media in election campaigns and should adapt the content of political messages to the characteristics of beginners.

The study above investigates the advantages and disadvantages of using online media in the 2020 Simultaneous Election campaign, where this election was held amid the Covid-19 pandemic, so digital campaigns should be an important means for Paslons to interact with their voters.

This study used the Campaign theory proposed by Rogers, EM, and Storey JD (1987) in the Handbook of Communication Science. Rogers and Storey defined a campaign as a series of planned communication actions to create a certain effect on many audiences that is carried out continuously over a certain period. Hence, the objective of this study is the extent to which the use of online media as a tool for organizing campaigns amid the Covid-19 pandemic in the Simultaneous Election of Mayor and Deputy Mayor of Semarang in 2020.

\section{RESEARCH METHOD}

The type of research is qualitative research with a case study approach. Qualitative research provides an opportunity to obtain data from local actors' expressions or, in the words of Clifford Geertz, "from the native's point of view". In addition, a case study is a comprehensive description and explanation of various aspects of an individual, a group, an organization (community), a program, or a social situation. The case study researcher attempted to examine as much data as possible about the subject of the study. They often used various methods such as interview, observation, document review, survey (results), and any data to describe the case in detail (Mulyana, 2002).

Informants in this study were determined by purposive sampling with parties directly related or with parties not directly involved. Still, they can provide views on the topic. The informants referred to the Campaign Team for The Candidate Pairs of Semarang Mayor, members of the General Election Commissions of Central Java Province, Semarang General Election Commissions, and the Semarang people.

Data collection techniques in this study used the following instruments: (1) Observation, (2) Survey Questionnaire, and (3) Interview. Made Observations by investigating the website and or social media of Semarang General Election Commissions, Semarang Election Supervisor, Candidate Pairs, and the Success Team. The survey was conducted randomly involving Semarang people with an age range of 17-35 years with 50 respondents who were distributed randomly. Interviews were conducted in a zoom meeting and via telephone to the Secretariat of Semarang General Election Commissions and Semarang Election Supervisor Members. The data collection stage started from March 8 to May 18, 2021.

The secondary data were obtained from literature and literature studies related to the study. Data collection was sourced from laws and regulations regarding the Implementation of Elections, General Election Commissions Regulations concerning Stages, Programs and Schedules of 2020 Regional Elections, General Election Commissions Regulations regarding the Implementation of regional elections amid the Covid 19 pandemic, General Election Commissions regulations challenging the 2020 Regional Election Campaign, reports on campaign implementation from Semarang General Election Commissions, comprehensive reports Election Supervisor, as well as other sources in the network (online).

Data analysis techniques in qualitative research were compiling data in the field, interview results, and documents by organizing data into categories, collecting patterns, choosing what is 
important and not, and making conclusions so that they were easily understood by themselves and others (Sugiyono, 2011). 2009).

\section{RESULTS AND DISCUSSION \\ 2020 Simultaneous Election Campaign}

The Election Campaign from now on referred to as the campaign based on Regulation of General Election Commission (PKPU) Number 13 of 2020, is an activity to convince voters by offering the vision, mission, and program of the candidate for governor and candidate for deputy governor, candidate for Mayor and candidate for deputy mayor, and candidate for regent and candidate for deputy regent. The 2020 Simultaneous Election campaign method was adapted to the conditions in Indonesia, which was being hit by the COVID-19 outbreak.

The PKPU, which regulates the 2020 Simultaneous Election campaign, has not specifically detailed the campaign model in the Regional Head Election in the application of online media and social media. Only limited meetings and face-toface meetings/dialogues that usually invite large crowds were now more emphasized through social media and online media. If did not do it through social media and online media, it must meet the General Election Commission Regulations requirements, such as limiting participants, being prohibited from bringing small children and toddlers, maintaining distance, wearing masks, and providing adequate sanitation. Campaign activities usually carried out and became the hallmark of the general election campaign in Indonesia. Public meetings, music concerts, healthy walks, social activities, and other activities involving crowds and mass mobilization were prohibited during the COVID-19 pandemic. The point is that in the 2020 election campaign, the emphas is was on digital campaigns by candidate pairs.
The General Election Commission Regulation explains the sanctions for participants if they continue to carry out activities prohibited in the campaign. The sanctions range from a written warning to the disbandment of campaign activities that do not comply with the health protocols of the Provincial/Regency/City General Election Supervisory Agency. However, in the online campaign, the form of sanctions for violating regulations from the General Election Commission or Bawaslu has not been regulated, and if fake content or news found that has an impact on public lies, elements of SARA, and on disinformation, the perpetrators who spread it will be subjected to the ITE Law.

In the 2020 Simultaneous Elections, Semarang includes 21 regencies/cities in Central Java, holding elections for regional heads and deputy regional heads. Based on Semarang General Election Commission data, the number of voters in the 2020 Simultaneous Elections was 1,174,068 people with a participation rate of 805,524 people or 68.62 percent. The number of valid votes is as many as 782,764 votes and invalid votes as many as 22,760 votes (https://kpu-semarangkota.go.id/).

The incumbent mayoral candidate and Semarang Deputy Mayor candidate set on September 23, 2020, was the sole pair in the 2020 Simultaneous Election. The teams of candidates for Mayor and Deputy Mayor Hendrar Priyadi and Hevearita Gunaryanti Rahayu were carried by all political parties in Semarang Regional People's Representative Assembly, namely the nine supporting parties, namely Nasdem Party and PSI, PKB, Democratic Party, PKS, PDIP, Golkar Party, Gerindra Party, PAN, in addition to the five supporting parties namely Berkarya Party, PBB, PKPI, PPP, and Hanura Party also supported this pair. Based on the vote recapitulation conducted by Semarang General Election Commission on December 17, 2020, this pair of candidates for Mayor and Deputy Mayor 
won 716,693 votes or 91.56 percent (https://kpu-semarangkota.go.id/).

\section{Online Media on Campaign Implementation in Semarang}

Based on the Semarang General Election Commission report book, the Stages of the 2020 Simultaneous Election Campaign will take place from September 26 to December 4, 2020. In Semarang, the campaign began with a declaration of peace with signing a peace campaign script and an integrity pact organized by the Semarang General Election Commission on September 29, 2020, at Gumaya Hotel Semarang. As an appeal from the General Election Commission that this campaign is emphasized online.

Based on Roger and Storey's campaign theory, every campaign activity aims to create a certain effect or impact, a big goal, at a certain time and through organized communication actions. For the public to understand the campaign message, the campaign message must have several functions, namely (1) changing people's mindsets, (2) achieving certain goals by raising public awareness and opinions, (3) persuading audiences, and (4) building a positive image (Venus, 2013).

The campaign method used by the Candidate Pairs Hendrar Prihadi and Hevearita Gunaryanti Rahayu used a combination of offline and online. These candidate pairs maximized the campaign this time through online and social media. However, some met face-to-face, such as attending social and religious activities but still following the limitations of the General Election Commission (Tobirin, Head of Technical Sub-section of Semarang General Election Commission).

Semarang General Election Commission also held two public debates during the 2020 simultaneous election period, held at Patra Hotel Semarang and broadcast live on Metro TV Semarang and streaming broadcasts on Hendar Prihardi's YouTube and social media with the limits required by the General Election Commission. From this public debate, the public is expected to assess the policies of the candidate pairs and gain public participation.

Candidates for Mayor and Deputy Mayor of Semarang officially registered their social media accounts with the Semarang General Election Commission regarding the media used for the campaign, namely Twitter and Instagram, on behalf of Hendita_2020. In addition to these two accounts, there was a personal account belonging to Hendrar Prihadi, who posted a lot of activities carried out during the 2020 Simultaneous Regional Head Election campaign. During the campaign and nominations at this time, the incumbent Mayor was quite active in posting on his Instagram and Twitter accounts. In his Twitter account, @hendrarprihadi has joined since 2012 and has published about 28 thousand tweets and reply tweets. Meanwhile, his Instagram @hendrarprihadi also posted 4,860 and was followed by around 268 thousand followers. In addition to Instagram and Twitter, Hendrar Prihadi also made a website www.hendrarprihadi.com which contains the profile, background, work program, and achievements of Hendrar Prihadi. In addition, Hendrar Prihadi is also active in social media, Facebook, Youtube channels, Tiktok and Telegram.

Can state that social media provides convenience in getting information and experiencing rapid development, including obtaining political information. Social media is one of the results of the development of technology.

In addition to the active campaign by the candidate pair in online media, HendiIta's campaign team and volunteers also collaborated with young influencers in Semarang to cast their votes in the 2020 Simultaneous Election. It is known that influencers are people who can influence society. They can be celebrities, bloggers, YouTubers, or a public figure considered 
important in a particular community. Generally, an influencer has millions of followers on social media. (Kurniawan, 2019).

Can state that Hendi-Ita will target the novice voter group in this Regional Head Election, where the meaning of novice voter is the voter who will be or have turned 17 years old on the voting date or day and will exercise their voting rights the first time. Based on data from the Semarang General Election Commission regarding the number of additional Voters List or DPTb, DPTb is an Additional Voter List, namely residents who already have voting rights but have not been registered in the DPT, are 17 years old, and are truly residents at the polling station following domicile since the resident has a Family Card or ID card in the area.

The results of uploading the DPTb for the 2020 Semarang Mayoral Election to Sidalih indicate that the number of novice voters reached 5,305 voters; of course, that is not a small number in electoral political contestation, especially in the 2020 Semarang Mayor and Deputy Mayor Election. Munzir (2019) stated that young Indonesians have good potential in politics since they can move dynamically and think critically.

Hendi-Ita partner also held a grand virtual campaign at the end of their campaign period on December 4, 2020. The great virtual drive used the Zoom application. Based on data from the HendiIta winning team, 26,832 people participated in the activity, and 7,200 accounts registered to get the virtual campaign link.

Based on the survey analysis that we have done, 90 percent of respondents used the internet and social media to access matters related to the election of Semarang Mayor and Deputy Mayor candidates, 90 percent of respondents know the profiles of Semarang Mayor and Deputy Mayor candidates through social media both Instagram and Twitter. The results indicate that 90.5 percent of respondents answered "yes" while only 9.5 percent stated "no". It means that it can be said to agree that candidate pairs used social media as a form of campaign.

Based on the survey results above, internet connection also affected difficulties or obstacles in participating in this online campaign. Culture and geographical aspects were also obstacles faced by some communities in this online campaign. Some community groups still thought that the movement must meet faceto-face with fellow support groups and Candidate Pairs. Attending public debates, convoys, orations, and public meetings and gatherings has become an inherent image of the campaign itself. Hence it is necessary to suggest a need for equitable distribution of the internet network and ease of accessing the internet so that people in every corner of the region can utilize the internet well.

\section{Utilization of Online Media in Campaign}

Online media, especially social media, have begun to be used intensively in the political aspect, with a more specific context. By the public, social media is used as a new medium to express political participation. Meanwhile, for politicians themselves, social media is a new means of establishing communication, building interactions, and disseminating political information to the public (Ardha, 2014). Based on social media and online media observations, can do it indicates a candidate's branding in advance. The candidates can first introduce themselves to the public through social media, which is used to build their self-image before entering the nomination stage.

In the report on the Implementation of the campaign by the Hendi-Ita Team to the General Election Commission and Semarang General Election Supervisory Agency, the drive was more virtual. The Hendi-Ita campaign team conducted a movement in the form of watching together through an electronic device in a large 
plasma screen connected to the internet that could be carried around or found at several post points. By using online video and the zoom meeting application, the public can still listen directly to the programs offered and the vision and mission of future leadership. In addition, the community can also interact directly and conduct discussions or ask questions.

Digital campaigns can also increase the creativity of candidate pairs and campaign teams in optimizing social media and existing networks. Through the cyber army, volunteers were aggressively communicating with the media by maximizing the role of social media, fans pages, Youtube channels, podcasts, and Whatsapp groups. Online media can encourage the campaign team to create and publish creative and educational content to the public.

Online campaigning also reduced conflict between supporters. By minimizing the number of meetings between supporters and the campaign, the team can neutralize the aura of division and conflict. Kamim stated the same thing (2017) the nature of campaigns on social media can be the opposite of movements in the real world. If in the real world the campaign is "noisy," loud but without concrete evidence, then on social media, it is a "meaningful" campaign. Every voice has a meaning, has its proof.

Online media was also used as a tool by the General Election Supervisory Agency to monitor and prevent violations. In collaboration with the General Election Commissions, Kominfo, and Semarang people, especially young people, Semarang General Election Supervisory Agency supervises any campaign violations through online media. As it is known that the nature of the internet is borderless, anytime anywhere, anyone can use the internet and spread campaign messages even though later it has entered a calm period, so it was difficult to monitor movements through this online media if there was no support from the community itself.

In addition, to carry out the prevention function, General Election Supervisory Agency compiles the Election Vulnerability Index (IKP) is a series of research carried out as the basis for formulating policies, programs, and monitoring strategies in the field of elections. The IKP also contains the level of vulnerability to Hate Speech and Ethnicity, Religion, Race, and Intergroups Politicization in all Regencies/Cities in Indonesia. Misinformation, Black campaigns, Coordinated non-authentic treatment (CIB) using fake/ anonymous accounts, use of bots and buzzers that point to certain issues/topics so that they are trending are the negative impacts of using internet technology social media in campaigning (Perludem, 2020).

The results of monitoring the campaign activities of Semarang Candidates on social media, Semarang General Election Supervisory Agency found violations related to the neutrality of ASN, several ASNs also gave support to Hendi through likes and comments on his Instagram posts, even classmates of public officials also shared photos. Together with Hendi on his old Facebook social media (Nining Susanti, Member of the Semarang General Election Supervisory Agency). Based on the recommendation of the Semarang General Election Supervisory Agency regarding the violation of the neutrality of the Civil Apparatus concerned, the KASN and the Regional Secretariat of the Semarang Government followed up with the imposition of a written sentence and light disciplinary punishment.

Based on Semarang General Election Supervisory Agency data, there were no online campaign violations in the 2020 Simultaneous Elections. According to Semarang General Election Supervisory Agency records, breaches in the Hendi-Ita campaign in the form of violations of health protocols were recorded in the 
Implementation of the Grand Virtual campaign on December 4, 2020, as many as 36 watching together virtual events were dissolved by the Semarang General Election Supervisory Agency since they did not have an online campaign notification letter.

The results of the supervision carried out by General Election Supervisory Agency during the Implementation of the Semarang election also found no violations regarding issues of Ethnicity, Religion, Race and Intergroup issues, Hoaxes, or black campaigns in campaign activities in Semarang. It indicates that the public can now control themselves with the existence of social media literacy to maintain election contestation in Indonesia so that the democratic political education in digital society continues to develop. Based on the results of an interview with General Election Supervisory Agency member Nining Susanti, the frequency of campaigning in Semarang was quite high among other single candidate pairs. It indicates that the limitation of meeting for campaigning does not dampen the intention and participation of candidate pairs and community members in Semarang to continue to participate in campaigning amid a pandemic such as this.

Benefits of Campaigns through online media also have a role in providing political education. Based on Kantaprawira (1998) views that political education is an effort to increase people's political knowledge and so that they can participate optimally in their political system for millennials who more often access information through social media platforms. This political education is very important; it can even state that online media has become a major factor in political education, so it needs to be delivered effectively and efficiently, especially during the Covid-19 pandemic.

Based on the description above, it can be concluded that the need for a redesign in the presentation of information using conventional and rigid methods in online media is no longer appropriate in the 4.0 revolution era. However, on the one side, the use of online media that was not accompanied by a good understanding of its use will result in misunderstandings or even violating existing regulations. In terms of increasing the credibility of political parties, it is necessary to have careful planning, communication, and program so that communication in the organization becomes an important thing to consider in developing platforms that exist in online media so that it can ascertain that online media plays an important role in political communication, especially in a political campaign.

There needs to be encouragement for election organizers, stakeholders, universities, and the government to implement a digital political education agenda (Nining Susanti, Member of Semarang General Election Supervisory Agency). Especially because of the COVID19 outbreak, which inevitably shifts the human paradigm or perspective from manual/traditional to digital. The use of online media is expected to strengthen friendship and discuss government policy, politics, and ethics of public figures, for instance, in building the image of political parties. Online media, especially social media, can also be an important part of every element such as communication, selfpromotion, socialization in people's lives. It is in line with what Munzir, Asmawi \& Aidil (2019) anyone who will enter the world of politics needs to have knowledge and skills in using social media.

\section{CONCLUSION}

The covid-19 pandemic has forced us to change the order of life and mindset from traditional to digital. The 2020 Simultaneous Regional Head Election is no exception, the stages of which are adjusted to the pandemic conditions, where one of these stages is the campaign. In Semarang, candidates for Mayor and Deputy Mayor of Semarang used online media to campaign in the 2020 Simultaneous Election. Online 
campaigns provided opportunities for candidate pairs to do branding in advance, through online media also increased the creativity of candidate pairs and success teams. Creating creative and educational content that was easy for the public to understand. This online campaign can reduce face-to-face conflicts in the community. From the organizer's side, online media can be used as a monitoring function. It can be used as a benchmark for the readiness of the Indonesian people in the use of Information and Communication Technology (ICT) tools in the General Election. The 2020 Simultaneous Regional Head Elections held during this pandemic can be considered the initial milestone for the birth of digital-based democracy. Campaigns through online media are also expected to be used as a means of political education for voters.

\section{BIBLIOGRAPHY}

Kamim, A. B. M. (2017). Sikap Media Daring Dalam Kontestasi Pilkada DKI 2017 (Analisis terhadap Sikap Media Daring dalam Isu Dugaan Penghinaan Kitab Suci Al-Qurâ€ $€^{\mathrm{TM}}$ an oleh Cagub Ahok dalam Rentang Pemberitaan 5 Oktober SD 20 Oktober 2016). Jurnal Komunikasi, 11(2), 189-200.

Alfian. (1981). Pemikiran dan Perubahan Politik Indonesia. Gramedia: Jakarta

Ardha, B. (2014). Social Media sebagai media kampanye partai politik 2014 di Indonesia. Jurnal Visi Komunikasi, 13(1), 105120.

Badan Pengawas Pemilu. (2019). Indeks Kerawanan Pemilu (IKP) 2019. Jakarta. Diunduh di https://www.bawaslu.go.id/id/publikasi/in deks-kerawanan-pemilu-ikp-2019/ Tanggal 12 Maret 2020.

Badan Pengawas Pemilu. (2020). Laporan Komprehensif Pemilihan Walikota dan Wakil Walikota Semarang Tahun 2020. Bawaslu Kota Semarang

Creswell, J.W., (2009). Research Design: Qualitative, Quantitative, and Mix Method Approaches. California: Sage Publication, Inc. Terjemahan Ahmad Lintang Lazuardi. Yogyakarta: Pustaka Pelajar.

Dimitrova, D. V., Shehata, A., Strömbäck, J., \& Nord, L. W. (2014). The effects of digital media on political knowledge and participation in election campaigns: Evidence from panel data. Communication Research, 41(1), 95-118.
Ulfa, G. S., \& Fatchiya, A. (2018). Efektivitas instagram "Earth Hour Bogor" sebagai media kampanye lingkungan. Jurnal Komunikasi Pembangunan, 16(1), 144-157.

Indrawan, J. Efriza, \& Ilmar, A. (2020). Kehadiran Media Baru (New Media) Dalam Proses Komunikasi Politik. Medium: Jurnal Ilmiah Fakultas Ilmu Komunikasi, 8(1), 1-17.

Kantaprawira, R. (1988), Sistem Politik Indonesia Suatu Model Pengantar Bandung: Sinar Baru

Komite Independen Sadar Pemilu. (2020). Menakar Iklim Demokrasi Digital di Pilkada 2020. Jakarta. Diunduh di https://kispid.org/08/2020/publikasi-kisp/policy-briefmenakar-iklim-demokrasi-digital-di-pilkada2020/ tanggal 8 Maret 2021.

Komisi Pemiluhan Umum. (2020). Laporan Tahapan Pemilihan Walikota dan Wakil Walikota Semarang. KPU Kota Semarang.

Kurniawan, S. (2019). Apa Itu Influencer dan Manfaatnya untuk Bisnis. Diunduh di https://www.niagahoster.co.id/blog/apaitu-influencer/ tanggal 3 Agustus 2021

Danuri, M. (2019). Perkembangan dan transformasi teknologi digital. INFOKAM, 15(2).

Mulyana, D. (2002). Metodologi Penelitian Kualitatif. Bandung: Remaja Rosdakarya.

Munzir, A. A. (2019). Beragam peran media sosial dalam dunia politik di Indonesia. JPPUMA: Jurnal Ilmu Pemerintahan dan Sosial Politik UMA Uournal of Governance and Political Social UMA), 7(2), 173-182.

Peraturan Komisi Pemilihan Umum Nomor 5 Tahun 2020 tentang Perubahan ke tiga atas Peraturan Komisi Pemilihan Umum Nomor 15 Tahun 2019 tentang Tahapan, Program dan Jadwal Penyelenggaraan Pemilihan Gubernur dan Wakil Gubernur, Bupati dan Wakil Bupati, dan/atau Walikota dan Wakil Walikota tahun 2020. Jakarta

Peraturan Komisi Pemilihan Umum Nomor 11 Tahun 2020 Tentang Perubahan Atas Peraturan Komisi Pemilihan Umum Nomor 4 Tahun 2017 Tentang Kampanye Pemilihan Gubernur Dan Wakil Gubernur, Bupati Dan Wakil Bupati, Dan/Atau Walikota Dan Wakil Walikota. Jakarta

Peraturan Komisi Pemilihan Umum Nomor 13 Tahun 2020 tentang Perubahan Kedua atas Peraturan Komisi Pemilihan Umum Nomor 6 Tahun 2020 tentang Pelaksanaan Pemilihan Gubernur dan Wakil Gubernur, Bupati dan Wakil Bupati, dan/atau Wali Kota dan Wakil Wali Kota Serentak Lanjutan dalam Kondisi Bencana Nonalam Corona Virus Disease 2019 (COVID-19). 2020. Jakarta

Perdana, A., \& Wildianti, D., (2018). Narasi Kampanye dan Media Sosial dalam Pemilu Presiden dan Wakil Presiden Tahun 2019. 
JPPUMA: Journal of Governance and Political Social UMA (UMA Journal of Governance and Political Social), 9 (2) (2021): 197-207

Puskapol LP2SP Fisip UI. Jurnal Bawaslu DKI Jakarta

Perkumpulan untuk Pemilu dan Demokrasi (Perludem). (2020). Press Rilis Temuan Awal Konten Kampanye Media Sosial Pilkada 2020. Jakarta.

http:/perludem.org/2020/12/06/temuanawal-konten-kampanve-media-sosialpilkada-2020. diakses pada 20 Maret 2021 pukul 10.00

Ratnamulyani, I. A., \& Maksudi, B. I. (2018). Peran Media Sosial Dalam Peningkatan Partisipasi Pemilih Pemula Dikalangan Pelajar Di Kabupaten Bogor. Sosiohumaniora, 20(2), 154-161.
Rogers, E.M \& Storey, J.D. (1987). Communication Campaign. Dalam C. R. Berger \& S.H. Chaffe (Eds.). Handbook of Communication Science. New Burry Park: Sage

Sugiyono. (2009). Metode Penelitian Pendekatan Kuantitatif, Kualitatif dan R\&D. Alfabeta: Bandung

Umayasari, U., \& Kurniawan, R. C. (2020). Dinamika Pilkada di Tengah Pandemi dalam Memenuhi Amanat Konstitusi. Wacana Publik, 14(02), 69-79.

Venus, A., (2013). Manajemen Kampanye: Panduan Teoritis dan Praktis dalam Mengefektifkan Kampanye Komunikasi. Bandung: Simbiosa Rekatama Media 